\title{
Investigating the Cost Management Practices of Indigenous Firms in the Ghanaian Construction Industry
}

\author{
Joseph Annor-Asubonteng, Callistus Tengan, Tom Mboya Asigri, \& Napoleon Kuebutornye D. K \\ Department of Building Technology, Bolgatanga Polytechnic, Bolgatanga, Ghana \\ annorasuo@gmail.com
}

\begin{abstract}
Cost management is key to project implementation and an important tool for maximizing profit nonetheless it has been a major challenge for most indigenous construction firms in Ghana. The study seeks to investigate the important factors influencing cost management practices among indigenous construction firms in Ghana and to ascertain whether there is a significant difference between the responses of the categories of the firm (construction and consultancy firms) in Ghana. A total of 82 questionnaires were retrieved from 100 administered questionnaires to professionals with indigenous construction firms representing $82 \%$ response rate. Data gathered were analyzed descriptively using Mean Item Score (MIS) via SPSS version 24 to identify the most important factors. The Kaiser-Meyer-Olkin Measure of Sampling Adequacy and Bartlett's test of sphericity conducted showed a KMO score of 0.894 . Bartlett's test of sphericity also revealed a significance level of $0.000(\mathrm{p}<0.05)$. The ANOVA suggest that there is no significant difference between the responses between the categories of firms. Indigenous firms are encouraged therefore to consider managing disagreement between project team members by ensuring constant project implementation meetings and to understand ground conditions of projects by visiting proposed sites prior to estimation and tendering. Finally, communication and expenditure control measures should be enhanced and introduced respectively. The implication of this study while contributing to the discourse on cost management practices of indigenous constructions firms in Ghana, also outlines the major (highly ranked) factors influencing indigenous firms in the management of project cost, before, during and after project implementation.
\end{abstract}

Keywords: Cost management, Ghana, Indigenous firms, Materials management, Project implementation,

\section{Introduction}

Cost is an essential component in the life cycle of projects which is used to define the success or failure of a project (Ali and Min 2017). Cost management (CM) therefore is a major component of project management and an important indicator to keep firms in the business. CM is necessary to ensure that the anticipated project is designed and developed within the projected cost to ensure value for money (Keith, 2008). John and Michael (1994) inform that CM requires careful identification of the activities that generate cost expenditures and ensuring such activities are carefully undertaken as planned. Similarly, Siebers et al., (2008) also inform that a major inefficiency among entities in the construction industry is due to its poor cost management practices. The menace of poor cost performance has been of concern globally (Zarina et al. 2014; Chen et al. 2016; Suk et al. 2016).

Nevertheless, the situation in developing countries is very alarming (Olatunji 2008) with Ghana not an exception, hence, the need for construction firms to adhere to cost management strategies is necessary to sustain profitability of all investments made as well as ensuring firm survival and growth (Ballard, 2010). Cost management includes tender estimating, cost planning and cost control. According to Tam, (2009) firms may lose its financial control and suffer cost overrun in a poor CM environment. Whiles the construction industry is dominated by indigenous firms, Pekuri et al., (2011) opines that indigenous firms are the most hit with the challenge of poor performance in managing project cost in the construction industry. The study therefore seeks to explore the important factors influencing cost management practices among indigenous construction firms in Ghana and to ascertain whether there is a significant difference between the responses of the categories of the firm (construction and consultancy firms) in Ghana.

\section{Cost Management Practices of Indigenous Firms in the Ghanaian Construction Industry}

Globally, the construction industry plays a significant role in contributing to the socio-economic development of every nation (Durdyev and Ismail, 2012). Durdyev and Ismail further describe the industry as powerful and remarkable in contributing to economic development through output generation, employment creation, income 
generation and re-distribution (Durdyev and Ismail, 2012). Similarly, economic development has been informed as a function of the performance of the construction industry (Oke et al., 2016). The importance of the Construction Industry in Ghana cannot be overemphasized since it remains a major driver of the Ghanaian economy. A study conducted by Hillebrandt (2000) revealed that the construction industry employs up to $10 \%$ of the working population and responsible for about $50 \%$ of the gross fixed capital formation. As early as the year 2013, the Ghana statistical service estimated the construction industry's contribution to the country's gross domestic product at ten-point five percent (10.5\%) (GSS, 2013) In spite of the gloomy impact of the construction industry however, cost planning and management is less practiced resulting in unsustainable cost overruns in the Ghanaian construction industry (Ernest et al., 2017) with indigenous contractors the worse culprits (Pekuri et al., 2011). The ensuing paragraph discusses the evolution of indigenous construction firm formation and the need for effective cost management practice by indigenous construction firms in Ghana.

The evolution of the indigenous contracting in Ghana dates as far back in the 1940's (Laryea and Mensah, 2010) and up to date have seen the proliferation of numerous indigenous construction firms emerged. Over the years the indigenous Ghanaian construction industry has attracted several expatriate construction firms who are competing for an opportunity in the industry. The indigenous firms have however been displaced due to the competitive advantage the expatriate firms exhibit; thus, advanced in construction technology and practice, project management practices and high level of manpower expertise. Contrary, many indigenous construction firms in Ghana today are confronted with the lack of capacity to carry out major projects because of low capitalization and poor organizational structures (Laryea and Mensah, 2010). This has seen the current construction market in Ghana being dominated by foreign contractors. The situation could be attributed to the harsh contracting environment faced by indigenous firms, and the late payment for work done (Laryea, 2010). Their technical capacity to manage projects explains the lapses accounted for in their cost management practices. Tengan et al., (2014) also blame indigenous firms for their poor planning and control techniques which have a burden on the cost implication of their operations.

The above-mentioned challenges hinder the core of cost management practices of indigenous firms. To overcome these cost challenges and be seen to grow in the Ghanaian construction industry, Laryea and Mensah, (2010) recommend that indigenous Ghanaian firms should establish strong organizational structures and pursue mergers and joint ventures to boost their financial, technical and managerial capacity. Similarly, Ghanaian indigenous firms ought to formulate the right strategic plans, develop innovative business strategies, and develop their professionalism to compete and remain relevant in their own environment. Project cost management, according to Godey, (2012) strategically focuses on the optimization of productivity and centres on the customer and on profitability. Hilton et al. (2001) inform that Project Cost Management is a "philosophy", an "attitude" and a "set of techniques" that guides the creation of more value at reasonable low cost. The need to have accurate cost and other vital information for decision making is met by effective project cost management. The accuracy of cost and the creation of more value at a lesser cost is a key factor in our world where only the fittest survive (Hilton et al., 2001). Proactive management of cost and behaviors includes the assessment, planning, controlling and evaluation of costs along the supply chain (Seuring, 2002).

To this, the significance of cost performance in the project cannot be overemphasized. It does not only highlight the profitability of a firm but also the productivity of the firm at any stage of the construction process (Meeampol and Ogunlan, 2006). CM is a thin000king of perfection by ensuring that the organization makes the right decisions to create more value at less cost to customers. Costs do not just happen but heavily depend on employing a set reliable technique (Hilton et al. 2001). CM generally takes one of the different forms, i.e., cost containment, cost prevention and cost lessening. A cost containment approach focuses on limiting or preventing future increases in fixed or unit variable costs. Cost prevention seeks elimination of activities generating costs that are not justifiable. Cost lessening lowers current fixed and variable costs associated with the crucial activity (John and Michael, 1994). Considering the nature of indigenous construction firms (small in size; low business capital; low human resource capacity etc.) and the poor project environment in which they operate (high competition; less technology adoption etc.) the need to manage cost in their operations is critical and a must do for indigenous firms to stay in the highly competitive construction industry.

The significance of Project Cost Management: The construction industry is heavily reliant on huge capital expenditure and must be managed well against both internal and external uncertainties. From construction 
management's point of view, the success of a project is measured based on the extent to which the project meets conforms to the agreed completion time, budget and quality. Whiles the importance placed on these success criterions may vary, the cost is the prime concern of the most client (Frimpong, 2000). Hence, Kim (2002) suggests that CM systems should include a set of processes such as cost estimating, cost control and cost projection to ensure that construction projects are completed within the approved budget. To ensure prudent $\mathrm{CM}$ the need to understand and analyse the cost structure of projects and its flow is imperative. Also, the reduction of inter-functional complexity, providing the tools that are necessary for cost management, involving stakeholders in cost related decisions, increase effectiveness and continuous improve on cost management. Finally measuring the decision made against the strategic plan of the project 000cannot be overstated. According to Horngreen et al., (1990) the strategic role of companies in staying relevant and competitive in the industry is significantly influenced by the effective implementation of CM by management. Andrea and Carlos, (2006) further argued in their study that a good project fails under poor management, and will usually face serious difficulties. Thus, poor project management structure have a detrimental effect on the construction process owing to the poor planning and coordination, ineffective communication among the project team, and late detection of defects in design. CM system should therefore be robust to support to protect the business from the harmful effects of uncertainty.

Factors Influencing Effective Cost Management Practices: Whiles it is imperative for indigenous construction firms in Ghana to manage cost to ensure firm growth, some practical challenges hinder their ability to effectively manage cost during the implementation of projects. A major canker that needs to be addressed properly is the cash flow of the project. John and Michael (1994) inform that strict adherence to relevant payment clauses and financial discipline by parties to the contract will keep project cash flow within budget. Similarly, poor budgetary and resource management, construction methods and ineffective communication will affect the effective CM practices of indigenous firms (Meeampol and Ogunlan, 2006). Ikediashi et al. (2014) also identified poor risk management, budget overruns, ineffective communication management, schedule delays and poor estimation practices as the top five significant cost failure factors. Furthermore, Memon et al. (2013) and Rahman et al. (2013) both identified money (finance) and contractors' site management related factors as critical factors affecting the cost performance in the Malaysian Construction Industry. Similarly, Al-Juwairah (1997) concluded that the most severe factors affecting construction costs from the contractors' perspective are: the unstable cost of construction materials; incorrect planning; contract management; wrong estimation methods; and lack of experience of the contractor in the management of project cost. This is further buttressed by Peeters and Madauss (2008), who also pointed out that the biggest contributing factor to poor cost management practices is the inaccuracy of project estimation due to poor project information available for the purpose of establishing initial project cost. A summary of the factors influencing effective CM practice is presented in table 1.

Table 1: Factors Influencing Effective Cost Management Practices

\begin{tabular}{|c|c|}
\hline Factors & Sources \\
\hline $\begin{array}{l}\text { Lack of adherence to relevant payment clauses and poor financial } \\
\text { discipline }\end{array}$ & John and Michael (1994) \\
\hline $\begin{array}{l}\text { Poor budgetary and resource management, construction methods and } \\
\text { ineffective communication }\end{array}$ & Meeampol and Ogunlan, 2006 \\
\hline $\begin{array}{l}\text { Poor risk management, ineffective communication management, } \\
\text { schedule delays and poor estimation practices }\end{array}$ & Ikediashi et al. (2014) \\
\hline Contractors' cash flow and site management challenges & $\begin{array}{l}\text { Memon et al. (2013); Rahman } \\
\text { et al. (2013) }\end{array}$ \\
\hline $\begin{array}{l}\text { Fluctuating cost of construction materials; incorrect planning; poor } \\
\text { contract management; wrong estimation methods; and lack of experience } \\
\text { of the contractor in the management of project cost }\end{array}$ & Al-Juwairah (1997) \\
\hline Inaccuracy of project estimation due to poor project information available & Peeters and Madauss (2008) \\
\hline
\end{tabular}

\section{Research Methodology}

A descriptive research design was adopted. The population for the study comprised professionals working with indigenous construction and consultancy firms in the Ghanaian construction industry. They included quantity 
surveyors, architects, engineers and clerk of works. These professionals were selected for the study owing to their association with the cost management activities of indigenous firms in project management. A hundred questionnaires were randomly administered to the target population. A total of eighty-two (82) questionnaires were received from forty-one (41) indigenous construction firms and forty-one (41) consultancy firms representing an eighty-two percent response rate. The Statistical Package for Social Science (SPSS) version 25 was utilized in analyzing the data collected. The Mean Item Score (MIS) of the factors influencing the cost management practices of indigenous firms in Ghana were analyzed to identify the most important factors. From Table 2, the Kaiser-Meyer-Olkin Measure of Sampling Adequacy and Bartlett's test of sphericity was conducted which recorded a KMO score of 0.894. Bartlett's test of sphericity also revealed a significance level of 0.000 $(\mathrm{p}<0.05)$. This suggests sample adequacy for the study. The analysis of variance (ANOVA) was further conducted to compare the views of respondents on the important factors on firms' characteristic.

Respondents were therefore asked to rate the level of importance of each significant variable on a 5-point Likert scale, where $1=$ Not at all important to $5=$ very important. The assumption for the determination of an important factor for the current study is based on the minimum mean score of 3.50 (Tengan et al., 2018). Sinesilassie et al (2018) also identified critical challenging factors of cost performance in the Ethiopian public construction projects as scope clarity, project manager's competence, conflict among project participants and project manager's ignorance and lack of knowledge. These finding are corroborating the conclusion reached by Iyer and Jha (2005) who identified conflict among project participants; ignorance and lack of knowledge; poor project-specific attributes; the non-existence of cooperation; hostile socio-economic and climatic conditions; reluctance to make timely decisions; aggressive competition during tendering; and short bid preparation times as the predominant factors that influence cost performance.

Table 2: KMO and Bartlett's Test of Sphericity

\begin{tabular}{lll}
\hline Kaiser-Meyer-Olkin Measure of Sampling Adequacy. & $\mathbf{. 8 9 4}$ \\
\hline Bartlett's Test of Sphericity & Approx. Chi-Square & 418.506 \\
& DF & 15 \\
& Sig. & .000 \\
\hline
\end{tabular}

\section{Findings}

The analysis was done in two in phases. Mean Item Score (MIS) test was used in the first phase to establish the most important factors influencing cost management practices of indigenous firms in Ghana. The second phase of the analysis used the Analysis of Variance (ANOVA) to determine whether a significant difference in the responses to the categories of firms is being studied. The two phases of the analysis and subsequent discussion have been presented below.

Demographic Data: The descriptive statistics provided a brief of the data collection and analyses of the questionnaire survey. The demographic characteristics of the respondents with respect to firm description, number of years of working experience, profession and academic qualification. Table 3 below presents an overview of the demographic characteristics of the respondents. Engineers and clerk of works (CoW) constituted $35.4 \%(\mathrm{n}=29)$ and $23.2 \%(\mathrm{n}=19)$ respectively. Finally, a greater majority of respondents who possessed bachelor degrees were made up of 40 representing a percentage aggregate of $48.8 \%$. This was followed by HND/ Diploma holders $(n=21 ; 25.6 \%)$, masters $(n=18 ; 22 \%)$ and $\mathrm{PhD}(\mathrm{n}=3 ; 3.7 \%)$.

Table 3: Demographic Characteristics of Respondents

\begin{tabular}{llll}
\hline Characteristics & Features & Frequency & Percentage \\
\hline \multirow{2}{*}{ A1: Firm Description } & Contractor & 41 & 50.0 \\
& Consultant & 41 & 50.0 \\
\multirow{2}{*}{ A2: Number of } & N & $\mathbf{8 2}$ & $\mathbf{1 0 0 . 0}$ \\
Respondents' Working than 1 year & 1-5years & 29 & $35.4 \%$ \\
Years' Experience & 5-10years & 33 & $40.2 \%$ \\
& 10years and above & 17 & $20.7 \%$ \\
\hline
\end{tabular}




\begin{tabular}{|c|c|c|c|}
\hline \multicolumn{4}{|c|}{$\begin{array}{c}\text { Journal of Economics and Behavioral Studies (ISSN: 2220-6140) } \\
\text { Vol. 10, No. 5, pp. 179-186, October } 2018 \\
\end{array}$} \\
\hline \multirow{5}{*}{$\begin{array}{l}\text { A3: } \\
\text { Profession }\end{array}$} & $\mathbf{N}$ & 82 & 100.0 \\
\hline & Quantity Surveyor & 12 & $14.6 \%$ \\
\hline & Architect & 22 & $26.8 \%$ \\
\hline & Engineer & 29 & $35.4 \%$ \\
\hline & Clerk of Works & 19 & $23.2 \%$ \\
\hline \multirow{5}{*}{$\begin{array}{l}\text { A4: } \\
\text { Qualification }\end{array}$} & $\mathbf{N}$ & 82 & 100.0 \\
\hline & HND/National Diploma & 21 & $25.6 \%$ \\
\hline & Bachelor & 40 & $48.8 \%$ \\
\hline & Masters & 18 & $22.0 \%$ \\
\hline & $\begin{array}{l}\mathrm{PhD} \\
\mathbf{N}\end{array}$ & $\begin{array}{l}3 \\
82\end{array}$ & $\begin{array}{l}3.7 \% \\
100.0\end{array}$ \\
\hline
\end{tabular}

From table 3, forty-one (41) respondents representating fifty percent (50.0\%) constituted construction firms whiles consultatnt firms also consituted the remaining fifty percent $(50.0 \%)$. Respondents years of esperience in the construction industry was categorised as less than 1 year $(n=29 ; 35.4 \%)$, between 1 and 5 years $(n=33$; $40,2 \%)$, between 5 and 10 years $(n=17 ; 20.7 \%)$ and above 10 years $(n=3 ; 3.7 \%)$. Also, $14.6 \%(n=12)$ of respondents were quantity surveyors whiles $26.8 \%(n=22)$ constituted architedts.

Significant Factors Influencing Cost Management Practice among Indigenous Construction Firms: Table 4 shows the significant factors that influence cost management practice among indigenous firms in Ghana. Eighty-two (82) indigenous construction firm professionals rated the influence of twelve (12) factors on a 5point Likert scale ranging from $1=$ Not at all important to $5=$ very important, and mean score (MS) ranging between 1.00 and 5.00. The study recorded a minimum and maximum mean score of 2.82 and 4.48 respectively indicating almost all twelve factors were rated important factors influencing cost management practices of indigenous firms. An assumed mean score greater than or equal to 3.5 was deemed a "very important" factor for each response (Tengan et al., 2018). From table 4, "Conflict between project parties/stakeholders" (client, contractors and consultant) was ranked the most significant factor influencing cost management among indigenous firms in Ghana recording mean score ( $M S=4.48$ ) and standard deviation score ( $S D=0.741)$. This was followed by both "unexpected ground condition" and "poor communication among parties" with MS of 3.90. Poor project management (MS=3.78; SD=1.031), Lack of expenditure control ( $M S=3.73 ; S D=1.066$ ), and Project variations/Design changes (MS=3.72; $\mathrm{SD}=1.069$ ) were ranked fourth, fifth and sixth respectively. Factors such as unexpected weather conditions, government policies, fluctuation in prices of raw materials, shortage of materials, the high cost of transporting materials and fraudulent practices and theft all recorded mean score less than $3.5(\mathrm{MS}<3.5)$ suggesting they do not influence the cost management practices of indigenous firms in Ghana based.

Table 4: Significant Factors Influencing Cost Management Practice of Indigenous Construction Firms

\begin{tabular}{llllll} 
Variables & N & MS & SD & Std. Error Mean & Rank \\
& & & & & \\
\hline CMPF1: Conflict between project parties / stakeholders & 82 & 4.48 & .741 & .082 & $1^{\text {st }}$ \\
CMPF2: Unexpected ground conditions & 82 & 3.90 & .964 & .106 & $2^{\text {nd }}$ \\
CMPF3: Poor communication between project team & 82 & 3.90 & 1.026 & .113 & $3^{\text {rd }}$ \\
CMPF4: Lack of expenditure control & 82 & 3.73 & 1.066 & .118 & $5^{\text {th }}$ \\
CMPF5: Project variations/Design changes & 82 & 3.72 & 1.069 & .118 & $6^{\text {th }}$ \\
CMPF6: Poor project management & 82 & 3.78 & 1.031 & .114 & $4^{\text {th }}$ \\
CMPF7: Unexpected weather conditions & 82 & 3.38 & 1.050 & .116 & $7^{\text {th }}$ \\
CMPF8: Government Policies & 82 & 3.21 & 1.284 & .142 & $8^{\text {th }}$ \\
CMPF9: Fluctuation in prices of raw materials & 82 & 3.16 & 1.083 & .120 & $9^{\text {th }}$ \\
CMPF10: Shortages of material & 82 & 3.11 & 1.054 & .116 & $10^{\text {th }}$ \\
CMPF11: Fraudulent practices and theft & 82 & 2.82 & 1.020 & .113 & $12^{\text {th }}$ \\
CMPF12: High cost of transportation of materials & 82 & 3.00 & 1.030 & .114 & \\
\hline
\end{tabular}


Discussion: Sinesilassie et al (2018) and Lyer and Jha (2005) both in separate studies identified conflict among project participants as a major factor affecting cost performance of construction projects, corroborating the findings of the current study as a conflict between project stakeholders was ranked first among twelve other factors. Material price increases (fluctuation) and High cost of transportation emerged significant factors influencing cost management practice of indigenous construction firms. Considering the road construction industry, the key materials needed especially for surfacing works are not readily available especially in the Northern parts of Ghana. It is a common phenomenon to see a construction firm who has deposited money for quarry products, having to wait for very long periods before deliveries are made. Under such circumstances, contractors are compelled to wait for a very long period for the supply of the said materials or alternatively resort to buying the same materials paid for from another source. This normally causes lockup capitals of construction firms who are already running on low capital inflows. This has the tendency of delaying the project and pushing up project cost through payment of idle labour and increased price of materials. This is similar to the findings of Olawale, and Sun (2010) who suggested a lack of materials and equipment, among other factors, presented difficulties to contractors' efforts to control project costs.

The above findings are also supported by the findings of Ikediashi et al. (2014) who concluded that poor communication management and poor estimation practices were critical cost failure factors. The interpretation of this results could mean that some contractors are not willing to employ the needed skilled manpower to manage their projects for them. Similarly, no market survey or materials price updates are done for the purpose of achieving realistic rates for a tender. Contractors however, result in intuition and old rates without incorporating adjustments for price increases. In addition, no efforts are made to visit the site to ascertain the pertaining site conditions before estimation of the bill items. Hence if the contractors are awarded such projects, the likelihood to encounter unexpected ground conditions and fluctuation in the cost of raw materials among others are very high. Effective communication and reporting on projects increase the efficiency of site operations and decrease any dispute, leading to cost and time savings. For instance, considering a typical road project with a lot of interdependent and sequential tasks, increase reliance on information exchanges during construction will go a long way to solve a lot of communication-related issues which can reduce drastically the menace of cost management related issues.

Analysis of Variance of Factors Influencing Cost Management Practice of Indigenous Construction Firms: The results of the analysis of variance of the factors influencing cost management practice of indigenous firms are presented in Table 5. It is hypothesized that, there is no significant difference between responses by the categories of the firm (contractors and consultant) on the important factors influencing cost management practices of the indigenous firm. After conducting the ANOVA test, a significance level of 0.883 was found for the factor "conflict between project parties/stakeholders". Similarly, significant scores of $0.495,0.669,0.148$, 0.609 and 1.00 were recorded for factors unexpected ground conditions, Poor communication between project team, Lack of expenditure control, Project variations/Design changes, and Poor project management respectively. This presents a significant $p$-value greater $0.05(p>0.05)$. These findings indicate that for all important factors influencing cost management practice of indigenous firms, the responses of respondents are the same; hence the study failed to reject the null hypothesis. Thus, the cost management factors are significant in influencing cost management practices of indigenous firms in the Ghanaian construction industry

Table 5: Analysis of Variance of Factors Influencing Cost Management Practice of Indigenous Firms

\begin{tabular}{|c|c|c|c|c|c|}
\hline & $\begin{array}{l}\text { Sum } \\
\text { Squares }\end{array}$ & $\begin{array}{l}\text { of } \\
\text { DF }\end{array}$ & $\begin{array}{l}\text { Mean } \\
\text { Square }\end{array}$ & $\mathbf{F}$ & Sig. \\
\hline CMPF1: Conflict betweenBetween Groups & .012 & 1 & .012 & .022 & .883 \\
\hline project parties / stakeholders Within Groups & 44.439 & 80 & .555 & & \\
\hline Total & 44.451 & 81 & & & \\
\hline CMPF2: Unexpected groundBetween Groups & .439 & 1 & .439 & .470 & .495 \\
\hline $\begin{array}{l}\text { Within Groups } \\
\text { Total }\end{array}$ & $\begin{array}{l}74.780 \\
75.220\end{array}$ & $\begin{array}{l}80 \\
81\end{array}$ & .935 & & \\
\hline CMPF3: Poor communicationBetween Groups & .195 & 1 & .195 & .184 & .669 \\
\hline $\begin{array}{l}\text { Within Groups } \\
\text { Total }\end{array}$ & $\begin{array}{l}85.024 \\
85.220\end{array}$ & $\begin{array}{l}80 \\
81\end{array}$ & 1.063 & & \\
\hline
\end{tabular}




\begin{tabular}{|c|c|c|c|c|c|}
\hline \multicolumn{6}{|c|}{$\begin{array}{c}\text { Journal of Economics and Behavioral Studies (ISSN: 2220-6140) } \\
\text { Vol. 10, No. 5, pp. 179-186, October } 2018 \\
\end{array}$} \\
\hline MPF4: Lack of expenditureBetween Groups & 2.390 & 1 & 2.390 & 2.132 & .148 \\
\hline Within Groups & 89.707 & 80 & 1.121 & & \\
\hline Total & 92.098 & 81 & & & \\
\hline ProjectBetween Groups & .305 & 1 & .305 & .264 & .609 \\
\hline variations/Design changes & 92.244 & 80 & 1.153 & & \\
\hline $\begin{array}{l}\text { projectBetween Groups } \\
\text { Within Groups } \\
\text { Total }\end{array}$ & $\begin{array}{l}92.549 \\
.000 \\
86.049 \\
86.049 \\
\end{array}$ & $\begin{array}{l}81 \\
1 \\
80 \\
81\end{array}$ & $\begin{array}{l}.000 \\
1.076\end{array}$ & .000 & 1.000 \\
\hline
\end{tabular}

\section{Conclusion and Recommendations}

To conclude, the study aimed at investigating the significant factors that influence cost management practice among indigenous firms in Ghana. The significant factors identified include conflict among project parties/stakeholders, unexpected ground conditions, poor communication between the project team, lack of expenditure control, project variations/design changes and poor project management. All the above six (6) factors had mean scores ranging between 3.72 to 4.48 which are well above the agreed mean score of 3.5 (MS $\geq 3.5$ ) (Tengan et al., 2018). Likewise, the Analysis of Variance (ANOVA) conducted revealed a significance p-value greater 0.05 . These findings indicate that all six factors are significant in influencing cost management practice of indigenous firms in Ghana. The study recommends therefore that indigenous firms manage team disagreement specifically by involving and collaborating with all project team members at all level of the project implementation. Also, project team communication needs to be enhanced as well as minimize wasteful expenditure on the project. Estimation for tendering should proceed with a visit to the project site to ensure that all necessary details such as ground conditions are considered and included in the cost build up. Qualified and experienced estimators and quantity surveyors who are the cost managers of projects with in-depth knowledge in cost management should be engaged by indigenous firms to improve the cost management practice. Finally, variation and design change management should be documented and administered well to record omissions and additions in the cost administration process.

\section{Reference}

Ali Mohammed A. \& Min Yi Chew. (2017). Simulation techniques for cost management and performance in construction projects in Malaysia, Built Environment Project and Asset Management, 7(5), 534-545.

Al-Juwairah, Y. (1997). Factors affecting construction cost in Saudi Arabia (master's thesis). King Fahd University of Petroleum and Mineral Dhahran Saudi Arabia.

Andrea, P. \& Carlos T. (2006). A model for integrating cost management and production planning and control in construction, Journal of Financial Management of Property and Construction, 11(2), 75 - 90.

Ballard, H. G. (2010). The last planner system of production control. Thesis submitted for the degree of Doctor of Philosophy, Faculty of Engineering, The University of Birmingham, 137.

Chen, Q., Jin, Z., Xia, B., Wu, P. \& Skitmore, M. (2016). Time and cost performance of design-build projects. J Constr Eng Manage. 142, 1-7.

Durdyev, S. \& Ismail, S. (2012). Role of the construction industry in the economic development of Turkmenistan. Changes, 64, 0.

Ernest, K., Theophilus, A. K. \& Edward, B. (2017). Exploring cost planning practices by Ghanaian construction professionals. International Journal of Project Organization and Management, 9, 83.

Frimpong, Y. (2000). Project management in developing countries: causes of delay and cost overruns in the construction of groundwater projects. Unpublished Masters Research Project, University of Technology, Sydney Australia.

Ghana Statistical Service (GSS 2013). (2010). Population \& Housing Census: National Analytical Report. Ghana Godey, Jim. (2012). Six Steps to Effective Cost Management (CPA in Industry), the CPA Journal Online Oct 1994. Hillebrandt, P. M. (2000). Economic Theory and the Construction Industry, 2nd Edition. Macmillan, Basingstoke. Hilton, R., Maher, M., Selto, F. \& Sainty, B. (2001). Cost Management: Strategies for Business Decisions. 1st ed., Ryerson, New York, McGraw-Hill. 
Horngreen, C. T., Foster, G. \& Srikant, M. D. (1990). Cost accounting: a managerial emphasis. 7th ed. Englewood: Prentice-Hall, 148.

Ikediashi, D. I., Ogunlana, S. O. \& Alotaibi, A. (2014). Analysis of project failure factors for infrastructure projects in Saudi Arabia: a multivariate approach. Journal of Construction in Developing Countries, 19, 35-52.

Iyer, K. \& Jha, K. (2005). Factors affecting cost performance: Evidence from Indian construction projects. International Journal of Project Management, 23, 283-295.

John, C. Groth. \& Michael, R. Kinney. (1994). Cost Management and Value Creation, Management Decision, 32(4), 52-57.

Keith Potts. (2008). Construction Cost Management Learning from case studies, Taylor \& Francis 2 Park Square, Milton Park, Abingdon, Oxon OX14 4RN page 3.

Kim, Y. (2002). Implications of a new production paradigm for project cost control. Berkeley, 149f. PhD Thesis, University of California.

Laryea, S. (2010). Challenges and opportunities facing contractors in Ghana, in: Laryea, S., Leiringer, R., Hughes, W. (Eds.), West Africa Built Environment Research (WABER) Conference. Accra, Ghana.

Laryea, S. \& Mensah, S. (2010). The evolution of indigenous contractors in Ghana, in: Laryea, S., Leiringer, R., Hughes, W. (Eds.), West Africa Built Environment Research (WABER) Conference. Accra, Ghana.

Meeampol, S. \& Ogunlan, S. O. (2006). Factors affecting cost and time performance on highway construction projects: Evidence from Thailand, Journal of Financial Management of Property and Construction, 11(1), 3-20,

Memon, A. H., Rahman, I. A., Azis, A. A. A. \& Abdullah, N. H. (2013). Using structural equation modelling to assess effects of construction resource-related factors on cost overrun. World Appl Sci J, 21, 6-15.

Oke, A., Ogungbile, A., Oyewobi, L. \& Tengan, C. (2016). Economic development as a function of construction project performance. Journal of Construction Project Management and Innovation, 6, 1447-1459.

Olatunji, O. A. (2008). A comparative analysis of tender sums and final costs of public construction and supply projects in Nigeria, Journal of Financial Management of Property and Construction, 13(1), 60-79.

Olawale, Y. \& Sun, M. (2010). Cost and time control of construction projects: Inhibiting factors and mitigating measures in practice. Construction Management and Economics, 28 (5), 509 - 526.

Peeters, W. \& Madauss, B. (2008). A proposed strategy against cost overruns in the space sector: The 5C approach. Space Policy, 24, 80-89.

Pekuri, A., Haapasalo, H. \& Herrala, M. (2011). Productivity and Performance Management - Managerial Practices in Construction Industry. International Journal of Performance Measurement, 1(1), 39-58.

Rahman, I. A., Memon, A. H., Azis, A. A. A. \& Abdullah, N. H. (2013). Modelling causes of cost overrun in large construction projects with partial least square-SEM approach: contractor's perspective. Res J Appl Sci Eng Technol, 5, 1963-1972.

Seuring, S. (2002). Supply Chain Costing - A Conceptual Framework, in: Cost Management in Supply Chains, Physica-Verlag, 15 - 30.

Siebers, P. O., Aickelin, U., Giuliana Battisti, Celia, H., Clegg, C., Fu, X., Hoyos, R. D., Iona, A., Petrescu, A. \& Peixoto, A. (2008). Enhancing Productivity: The Role of Management Practices. AIM Working Paper Series 062 - February 2008.

Sinesilassie, E. G., Tabish, S. Z. S. \& Jha, K. N. (2018). Critical factors affecting cost performance: a case of Ethiopian public construction projects, International Journal of Construction Management, 18(2), 108119.

Suk, S. J., Chi, S., Mulva, S. P. Caldas, C. H. \& An, S. H. (2016). Quantifying combination effects of project management practices on cost performance. KSCE Journal of Civil Engineering, 1-13.

Tam, C. M. \& Fung, Ivan W. H. (2009). Effectiveness of Safety Management Strategies on Safety Performance in Hong Kong, Construction Management and Economics, 16, 49-55.

Tengan, C., Aigbavboa, C. O. \& Oke, A. E. (2018). Evaluation of UFPA quality assessment criteria for monitoring and evaluation system in the Ghanaian construction industry. African Journal Science, Technology Innovation Development, 1-5.

Tengan, C., Anzagira, L. F., Kissi, E., Balaara, S. \& Anzagira, C. A. (2014). Factors Affecting Quality Performance of Construction Firms in Ghana: Evidence from Small-Scale Contractors. Civ. Environ, 6, 18-23.

Zarina, A., Zawawi, E. M. A., Yusof K. \& Aris, N. M. (2014). Determining critical success factors of project management practice: a conceptual framework. In: Proceedings of the AMER International Conference. 